\title{
PENGARUH PENGGUNAAN MODEL PENGELOMPOKAN, MODEL LUAS DAERAH DAN MODEL GARIS BILANGAN DALAM PENANAMAN KONSEP PECAHAN UNTUK PEMBELAJARAN OPERASI PECAHAN
}

\section{THE EFFECT OF USING GROUPING MODELS, REGIONAL AREA MODELS AND NUMBER LINE MODELS IN FRACTION OPERATIONS LEARNING IN TERMS OF VERBAL ABILITY}

\author{
I Made Surat \\ Program Studi Pendidikan Matematika FPMIPA IKIP PGRI BALI, Bali, Indonesia \\ Email: madesurat@gmail.com
}

Diterima: 20 Januari 2020. Disetujui: 1 Februari 2020. Dipublikasikan: 2 Maret 2020

\begin{abstract}
Abstrak: Penelitian ini bertujuan untuk mengetahui perbedaan pengaruh antara pembelajaran konsep fraksi dengan model pengelompokan, model area area, dan model garis angka dalam menanamkan konsep fraksi dalam hal tingkat kemampuan verbal pendidik. Penelitian ini adalah perlakuan faktorial eksperimental dengan level $3 \times 2$, dengan populasi 188 orang. Terdiri dari semua siswa sekolah dasar kelas empat di Desa Darmasaba, Distrik Abiansemal, Kabupaten Badung. Sampel penelitian diambil menggunakan teknik double step group, dengan jumlah sampel 120 siswa. Data penelitian ini diperoleh melalui tes dan nilai rapor. Data dianalisis dengan teknik analisis varians, dengan frekuensi sel yang tidak sama. Tes persyaratan analisis termasuk uji distribusi normalitas dan uji homogenitas varians, masing-masing menggunakan statistik Lilieffors dan statistik Levene. Dari hasil analisis statistik deskriptif diketahui bahwa persentase penguasaan konsep fraksi yang meliputi, (1) pemahaman fraksi peserta didik dalam kelompok belajar fraksi dengan model pengelompokan, model area dan model garis bilangan, masing-masing 63\%, 65,8\% , dan 60\%; (2) pemahaman siswa tentang konsep nilai pecahan (PKPS) dalam kelompok belajar konsep fraksi dengan model pengelompokan, model area dan model garis bilangan masing-masing 50\%, 59\% dan 59,5\%; (3) kemampuan siswa untuk melakukan operasi penambahan dan pengurangan fraksi (KOPP) dalam kelompok belajar konsep fraksi dengan model pengelompokan, model area regional dan model garis bilangan, masing-masing 52\%, 59\% dan 56,2\%. Hasil analisis varians untuk uji over all pada ketiga kelompok menunjukkan hasil yang sangat berbeda. Dalam PKPS penanaman nilai F-hit $=12,193$ dan peluang kesalahan $\mathrm{p}<0,01$, serta interaksi antara model dan kemampuan verbal dengan nilai F-intr $=6,833$ pada tingkat signifikansi yang signifikan $<0,01$. Demikian juga, KOPP memperoleh nilai F-hit $=6,59$ dan nilai $p<0,01$ dan ada interaksi dengan nilai $\mathrm{F}=6,47$ dan $\mathrm{p}<0,01$. Dengan interaksi, dilanjutkan dengan perbandingan rata-rata antara sel dalam kelompok siswa dengan tingkat kemampuan verbal rendah, menunjukkan: (1) pembelajaran konsep fraksi dengan model regional dan model garis bilangan menunjukkan hasil yang lebih baik dari pembelajaran konsep fraksi dengan model pengelompokan di menanamkan PKPS ( $t=5,59$ dengan $\mathrm{p}<0,01$ dan $\mathrm{t}$ $=4,13$ dengan $\mathrm{p}<0,01)$; menuju KOPP, pembelajaran konsep fraksi dengan model area menunjukkan hasil terbaik dari model pengelompokan dan model garis bilangan $(t=5,29$ dengan $p<0,01$ dan $t=3,08$ dengan $p<0,01$, sedangkan pembelajaran konsep fraksi dengan model garis $\mathrm{b}$ efektivitas yang sama dengan model pengelompokan $(t=2.197$ dengan nilai $p>0,01)$; (3) efek menggunakan model baik dalam penanaman PKPS dan pada KOPP tergantung pada tingkat kemampuan verbal siswa. Berdasarkan temuan di atas, dapat disarankan kepada Guru Sekolah Dasar dalam mengajar matematika, bahwa dalam pembelajaran konsep fraksi harus memprioritaskan penggunaan model area kemudian dapat diikuti oleh model garis bilangan.
\end{abstract}

Kata kunci: Model Pengelompokan, Model Area Area, Model Line Number, Kemampuan Verbal dan Operasi Fraksi.

\begin{abstract}
This study aims to determine the difference in influence between fraction concept learning with grouping models, area area models, and number line models in embedding fraction concepts in terms of the level of verbal ability of educators. This research is an experimental factorial treatment by level $3 \times 2$, with a population of 188 people. Consisting of all fourth-grade elementary school students in Darmasaba Village, Abiansemal District, Badung Regency. The research sample was taken using a double step group technique, with a sample size of 120 students. The data of this study were obtained through tests and report card grades. Data were analyzed by variance analysis techniques, with unequal cell frequencies. Tests of analysis requirements including normality distribution tests and variance homogeneity tests, respectively using Lilieffors statistics and Levene statistics. From the results of descriptive statistical analysis it is known that the percentage of mastery of fraction concepts which includes, (1) learners' understanding of fractions in fraction learning groups with grouping models, area models and number line models, respectively $63 \%, 65.8 \%$, and $60 \%$; (2) students' understanding of the concept of fractions worth (PKPS) in fraction concept learning groups with grouping models, model area and number line models respectively $50 \%, 59 \%$ and $59.5 \%$; (3) the ability of students to carry out fraction addition and subtraction operations (KOPP) in fraction concept learning groups with grouping models, regional area
\end{abstract}


models and number line models, respectively $52 \%, 59 \%$ and $56.2 \%$. The results of the variance analysis for the over all test in the three groups showed significantly different results. In PKPS planting F-hit value $=12,193$ and opportunity error $\mathrm{p}<0,01$, as well as interaction between model and verbal ability with F-intr value $=6,833$ at signi fi can't level of significance $<0,01$. Likewise, KOPP obtained value F-hit $=6.59$ and $p$ value $<0.01$ and there was an interaction with the values $F=6.47$ and $p<0.01$. With the interaction, it is continued with a comparison of mean between cells in groups of students with low verbal ability level, showing: (1) fraction concept learning with regional model and number line model shows better results from fraction concept learning with grouping models in instilling PKPS $(t=5.59$ with $\mathrm{p}<0.01$ and $\mathrm{t}=4.13$ with $\mathrm{p}<0.01)$; towards KOPP, fraction concept learning with area model shows the best results from grouping models and number line models $(\mathrm{t}=5.29$ with $\mathrm{p}$ $<0.01$ and $t=3.08$ with $\mathrm{p}<0.01$ ), while learning the fraction concept with a number line model has the same effectiveness as the grouping model $(\mathrm{t}=2.197$ with a value of $\mathrm{p}>0.01)$; (3) the effect of using the model both in PKPS planting and on KOPP depends on the level of verbal ability of the students. Based on the findings above, it can be suggested to Elementary Teachers in teaching mathematics, that in fraction concept learning should prioritize the use of the area model then can be followed by a number line model.

Keywords: Grouping Model, Area Area Model, Number Line Model, Verbal Ability and Fraction Operation.

\section{PENDAHULUAN}

Matematika merupakan salah satu mata pelajaran yang sangat penting diajarkan di jenjang pendidikan dasar. Sebagai pengetahuan, bahwa matematika mempunyai cirri-ciri khusus antara lain, bersifat abstrak, deduktif, konsisten, hierarkis dan logis [1]. Jadi belajar matematika akan dapat memberikan kemampuan hitung sebagai dasar kemampuan numeric, juga dapat memberikan kemampuan penalaran, dan bahasa. Kemampuankemampuan seperti ini sangatlah bermanfaat untuk menyerap dan mengembangkan keilmuan lebih lanjut. Oleh karena itu maka perlu kiranya diupayakan agar peserta didik semakin menyenangi dan dapat menyerap konsep-konsep matematika. Namun kenyataan bahwa sampai sekarang ini mata pelajaran matematika masih menjadi pelajaran yang sulit untuk dipelajari sehingga menjadi momok bagi kebanyakan peserta didik.

Salah satu topik matematika yang sulit difahami oleh peserta didik di SD adalah konsep pecahan. Pecahan merupakan topik kelanjutan dari bilangan bulat. Konsep bilangan bulat belum cukup untuk memenuhi berbagai kepentingan manusia. Hal-hal yang belum dapat dipenuhi oleh system bilangan bulat antara lain adalah menyatakan beberapa bagian yang sama dari keseluruhan, menyatakan banyaknya beberapa benda dari sejmlah benda, menyatakan hasil pengukuran. Kenyatakan di masyarakat memerlukan bilangan-bilangan antara 0 dan 1 , antara 1 dan 2 , antara 2 dan 3 dan seterusnya. Tanpa perluasan bilangan bulat ke dalam system bilangan rasional khususnya bilangan pecahan, maka persoalan berikut 1:2 $=x, 5: 3=x$ tidak mempunyai penyelesaian.

Kenyataan menunjukkan bahwa masih banyak peserta didik di SD yang kesulitan memahami konsep pecahan. Kegagalan peserta didik dalam menyelesaikan soal pecahan disebabkan oleh kurangnya pemahaman siswa terhadap konsep pecahan [2]. Konsep pecahan tidaklah sesederhana konsep bilangan cacah. Bilangan cacah terkait dengan himpunan diskret, sedangkan konsep pecahan terkait dengan perbandingan, himpunan diskret dan himpunan kontinu. Dari konsep tentang perbandingan, himpunan diskret dan himpunan kontinu dapat dikembangkan model-model penyajian untuk menanamkan konsep pecahan, yaitu model pengelompokkan, model luas daerah dan model garis bilangan.

Dalam mempelajari operasi pecahan hal yang penting dikuasai siswa adalah konsep pecahan senilai. Penguasaan yang kurang memadai atas konsep pecahan senilai akan menghambat siswa dalam melakukan operasi pecahan, terutama dalam hal membandingkan dua buah pecahan [3]. Konsep pecahan berkaitan dengan perbandingan sifat bilangan dua himpunan. Ide tentang perbandingan merupakan ide yang paling bermanfaat dalam menjembatani konsep bilangan cacah dan konsep pecahan. Penguasaan ide perbandingan ini selanjutnya akan dapat dipergunakan untuk memecahkan soal-soal pecahan berbentuk cerita [4].

Tingkat kematangan siswa berkembang sejalan dengan pertambahan usianya. Jika mengacu pada teori perkembangan kognitif dari Jean Piaget, maka peserta didik SD kelas IV yang rata-rata berusia 10-11 tahun, kemunkinan besar masih berada pada tahap operasi konkret. Hal ini berarti bahwa anak pada tahap ini masih memerlukan benda-benda konkret maupun semi konkret dalam memahami konsep dasar pecahan. Dalam menggunakan model penyajian pecahan untuk menanamkan konsep pecahan hendaknya juga mempertimbankan tingkat kemampuan verbal dari peserta didik. Tingkat kemampuan verbal akan mewarnai kemampuan peserta didik dalam memahami bahasa yang digunakan guru dalam menyajikan pecahan.

\section{Pemahaman Konsep}

Tiga kemampuan dasar yang harus dikuasai oleh peserta didik di SD adalah kemampuan baca, tulis dan hitung. Di antara ketiga ketiga kemampuan tersebut, kemampuan baca dan hitung perlu mendapat penekanan. Aspek 
kemampuan memuat tiga unsur yakni prestasi, kecakapan dan kecerdasan. Kemampuan yang dimaksud dalam hal ini adalah kemampuan yang tercermin pada hasil belajar yang merupakan kemampuan aktual yang dapat diukur dengan test [5]. Pemahaman diartikan sebagai kemampuan untuk menangkap makna dan arti dari bahan yang dipelajari [6]. Adanya kemampuan peserta didik dalam memahami suatu konsep, ditujukan dalam uraian isi pokok dari suatu bacaan, mengubah data yang disajikan dalam bentuk tertentu ke dalam bentuk yang lain yang dinyatakan dengan kata-kata. Dengan pemahaman tersbut maka peserta didik akan mengetahui hubungan antara fakta-fakta, konsep dan prinsip. Pemahaman sebagai penyerapan arti. Pemahaman meliputi tiga macam, yaitu pengubahan, pemberian arti, dan pembuatan ekstrapolasi [7]. Dalam hal pemahaman suatu konsep peserta didik diarahkan untuk mampu mengartikan suatu model ke dalam kehidupan sehari-hari dan sebaliknya menunjuk model dari suau symbol. Dalam menanamkan pemahaman atas konsep pecahan, sedapat mungkin pada tahap-tahap awal penyajian dimulai dengan menggunakan benda-benda konkret maupun semi konkret hingga dilanjutkan ketahap berikutnya yaitu abstrak.

Ada tiga jenis konsep dalam matematika yaitu konsep murni, konsep notasi, dan konsep penggunaan [8]. Konsep murni merupakan prasyarat konsep notasi, konsep notasi merupakan prasyarat konsep penggunaan. Pernyataan Dienes itu menunjukkan bahwa belajar matematika itu bersifat terstruktr secara hierarkis. Dalam hal ini konsep murni adalah konsep pecahan. Konsep pecahan ini akan bermanfaat dalam memahami dan menerapkan konsep penggunaan yakni dalam melakukan operasi pecahan. Hal ini sejalan dengan Belajar konsepkonsep abstrak dalam matematika diperlukan pemahaman akan konsep dasar dan teori. Belajar matematika yang cocok adalah belajar konsep dan struktur [3]. Pemahaman yang memadai mengenai konsep dan struktur pecahan menjadikan bahasan pecahan tersebut lebih mudah dipahami. Selain itu siswa juga lebih mudah mengingatnya. Konsepkonsep yang telah tertanam dalam pikiran anak perlu dimantapkan dengan latihan-latihan sebagai keterampilan dan penguasaan algoritma. Melalui pemahaman terhadap konsep dan struktur yang dimantapkan dengan penguasaan algoritma akan mempermudah transfer belajar.

\section{Makna Pecahan}

Untuk dapat memahami makna pecahan maka konsep bilangan cacah harus sudah dipahami. Inilah struktur yang bersifat hierarkis dalam matematika. Setiap bilangan cacah terkait dengan himpunan diskret, sedangkan pecahan terkait dengan: (a) pengelompokan himpunan; (b) perbandingan sifat dua bilangan himpunan; (c) bilangan dari himpunan yang terpisah; (d) bilangan yang mewakili perbandingan dua himpunan [4]. Pecahan adalah merupakan bilangan rasional (Gatot Muhsetyo, dkk., 2014). Ini berarti bahwa pecahan adalah bilangan yang lambangnya dapat ditulis dalam bentuk $a / b$, dengan $a$ dan $b$ adalah bilangan bulat, dan $b$ tidak sama dengan Nol. Pada pecahan $a / b$, a disebut dengan pembilang dan $b$ adalah penyebut.

Terdapat 7 model untuk menyatakan pecahan yaitu sbb [9]:

1). Part-group, Congruent-part

Pecahan dinyatakan sebagai bagian dari suatu kelompok dengan anggota yang kongruen. Dalam hal ini peserta didik mengasosiasikan pecahan $\mathrm{a} / \mathrm{b}$ dengan suatu kelompok yang terdiri dari anggota sebanyak b, dengan hanya memperhatikan bagian dari anggota sebanyak a kelompok tersebut. Contoh $\mathrm{a}=3$ dan $\mathrm{b}=4$, seperti gambar berikut:

Gambar 1:

Peragaan Pecahan $3 / 4$, ada 3 yang berbayang hitam dari 4 objek keseluruhan.

\section{2). Part-Whole, congruent-part}

Pecahan dinyatakan sebagai bagian dari suatu satuan yang terbagi atas bagian yang kongruen.Siswa mengasosiasikan pecahan $\mathrm{a} / \mathrm{b}$ dengan daerah geometris yang dibagi kedalam $b$ bagian yang kongruen, dan memperhatikan a bagian.

\section{Contoh:}

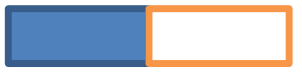

Gambar 2: Peragaan pecahan 3/4(arsiran) dengan menggunakan model luas daerah yang bagianbagiannya kongruen.

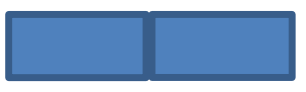

\section{3). Part-group, non congruent-part}

Pecahan dinyatakan sebagai bagian dari suatu kelompok yang bagian-bagiannya tidak kongruen.Siswa mengasosiasikan pecahan $a / b$ dengan suatu kelompok yang terdiri dari b objek yang tidak kongruen dan memperhatikan a objek dalam kelompok tersebut.I

Contoh:
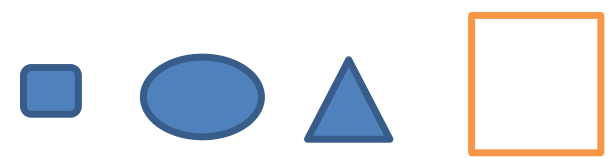

Peragaan pecahan 3/4 (yang diarsir) dengan menggunakan himpunan yang bagian-bagiannya tidak kongruen.

\section{4). Part-group comparison}

Pecahan dinyatakan sebagai bagian dari suatu kelompok dengan perbandingan.Siswa mengasosiasikan pecahan $\mathrm{a} / \mathrm{b}$ dengan perbandingan relative dua kelompok A dan B. Dalam hal ini banyaknya objek pada kelompok $\mathrm{A}$ adalah a, dan 
banyaknya objek pada kelompok B adalah b. Semua objek kongruen.

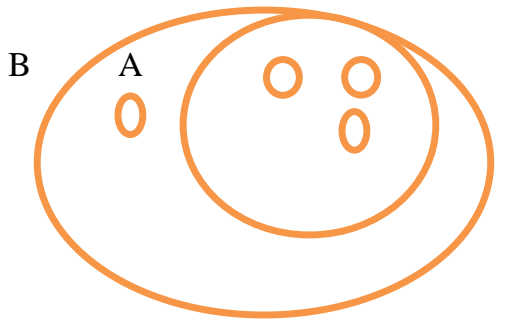

5). Number Line

Konsep pecahan diperagakn dengan menggunakan garis bilangan. Siswa mengasosiasikan pecahan $\mathrm{a} / \mathrm{b}$ dengan suatu titik pada garis bilangan. Setiap satuan segmen garis itu sudah dibagi ke dalam b bagian yang sama, dan titik a pada garis bilangan menyatakan relasi ini. Contoh:

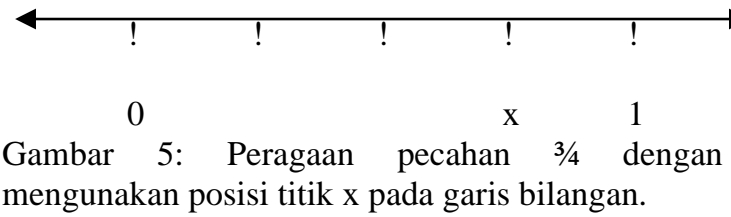

\section{6). Part-whole comparison}

Konsep pecahan yang dinyatakan sebagai bagian dari suatu daerah dengan perbandingan. Siswa mengasosiasikan pecahan $\mathrm{a} / \mathrm{b}$ dengan perbandingan relatif dua daerah geometris A dan B. Jumlah bagian yang kongruen dalam $\mathrm{Gb}$ A adalah a, sedang pada Gb B adalah b.

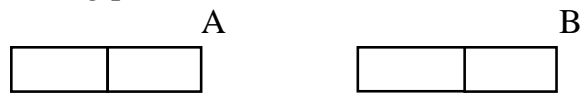

Gambar 6: Peragaan pecahan 3/4 dengan menggunakan perbandingan dua luasan yg bagianbagiannya kongruen.

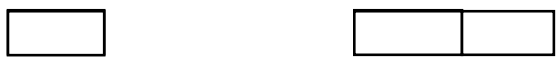

\section{7). Part-whole non congruen part}

Konsep pecahan yang dinyatakan sebagai bagian dari suatu daerah, yang bagian-bagiannya tidak kongruen. Siswa mengasosiasikan pecahan $\mathrm{a} / \mathrm{b}$ dengan daerah geometris yang sudah dibagi ke dalam b yang sama dalam luas tetapi tidak kongruen dan memperhatikan bagian. Contoh:

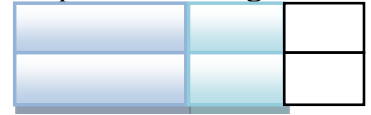

Gambar 7: Peragaan Pecahan 3/4 (arsiran) dengan menggunakan luas daerah yang bagian-bagiannya tidak kongruen

Dari 7 subkonsep di atas, dapat dikelompokkan menjadi 3 model, yakni Model Himpunan yang dibentuk dari sub konsep 1,3 dan 4. Model Luas Daerah yang dibentuk dari subkonsep 2,6 dan 7. Model Garis Bilangan yang dibentuk dari subkonsep 5 .

\section{Konsep Pecahan Senilai}

Penguasaan atas konsep pecahan senilai merupakan prasyarat untuk dapat menyelesaiakan operasi pecahan. Dua pecahan $\mathrm{a} / \mathrm{b}$ dan $\mathrm{c} / \mathrm{d}$ mempunyai nilaai yang sama jika axd $=$ bxc. Kita katakana bahwa $2 / 3$ senilai dengan 4/6 karena berlaku $2 \times 6=3 \times 4$. Jadi pecahan senilai lambangnya berbeda namun nilainya sama. Manfaat mempelajari pecahan senilai adalah, (1) kemampuan mengurutkan pecahan; (2) kemampuan menjumlahkan dan mengurangkan pecahan [10]. Menentukan pecahan senilai dari suatu pecahan yang diketahui dapat dilakukan dengan pendekatan semi konkret yang diperagakan dengan model pengelompokkan, luas daerah, maupun garis bilangan. Contoh dalam memperagakan $1 / 2=2 / 4=$ $3 / 6=\ldots .$.

-Model Pengelompokkan:

$\bigcirc \ominus$,

-Model Luas Daerah

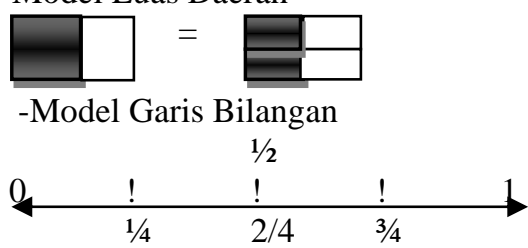

\section{Kemampuan Verbal}

Bahasa yang digunakan dalam matematika bersifat formal dan taat azas. Definisi-definisi disajikan dengan bahasa yg efektif dan efisien, tidak mengandung makna ganda. Fungsi yang paling mendasar dari bahasa adalah menjelmakan pemikiran konseptual ke dalam dunia kehidupan [11]. Untuk menguji kebenaran dari pemikiran konseptual dalam matematika, maka harus diubah dengan menggunakan symbol-simbol. Simbol yang digunakan harus bercorak ideografik, artinya hanya mewakili satu ide. Simbol ini bermanfaat untuk menghemat intelektual, sebab symbol dapat mengkomunikasikan ide-ide secara efektif dan efisien. Pengetahuan verbal adalah pengetahuan yang dimiliki seseorang yang diungkapkan dalam bentuk bahasa lisan atau tulisan [12]. Pengetahuan verbal meliputi cap verbal dan data atau fakta. Cap verbal yaitu kata yang dimiliki seseorang untuk menunjuk objek-objek yang dihadapi, misalnya pecahan. Data atau fakta adalah kenyataan yang diketahui. Anak-anak pada tahap operasi konkret mampu menyelesaikan masalah secara logis bila masalah tersebut disajikan dengan menggunakan bahasa yang sederhana [13]. Sesuatu yang sangat penting dalam soal verbal adalah "menterjemahkaan" situasi masalah ke dalam kalimat matematika [14]. Kemampuan verbal dalam matematika meliputi kemampuan memahami dan mengingat kata-kata, istilah-istilah matematika yang terdapat dalam soal. 


\section{METODE PENELITIAN}

Penelitian ini dilakukan di SD Negeri se Desa Darmasaba, Kecamatan Abiansemal Badung. Waktu penelitian ini pada semester I Th 2018. Jenis penelitian ini adalah penelitian eksperimen factorial $3 \times 2$ dengan treatment by level. Tiga perlakuannya adalah (1) model pengelompokkan; (2) model luas daerah; dan (3) model garis bilangan. Perlakuan tersebut diberikan pada kelompok dengan kemampuan verbal tinggi dan rendah. Berikut ini adalah Tabel 1.

Tabel 1. skema Rancangan Faktorial 3x2

\begin{tabular}{|c|c|c|}
\hline \multirow{2}{*}{$\begin{array}{l}\text { Fakt. B } \\
\text { Fakt. A }\end{array}$} & \multicolumn{2}{|c|}{ Kemampuan Verbal } \\
\hline & Tinggi & Rendah \\
\hline $\begin{array}{l}\text { Modl Penglpkan } \\
\text { Modl. Luas D. } \\
\text { Modl. Grs Bilgn }\end{array}$ & & \\
\hline
\end{tabular}

Populasi penelitian ini adalah seluruh peserta didik Kls IV dari 7 SD N Darmasaba yang berjumlah 188 orang. Dalam menentukan besarnya sampel mengacu pada rancangan yang digunakan dengan rumus :

$\mathrm{n}^{\prime}=\frac{\mathrm{N}-\mathrm{pq}}{(\mathrm{p}-1)(\mathrm{q}-1)+1}+1[15]$

Ket.: $\mathrm{N}=$ Ukuran sampel; $\mathrm{P}=$ banyak faktor $\mathrm{A} ; \mathrm{q}=$ banyak factor $\mathrm{B}$; $\mathrm{n}$ ' = harga dalam Tabel berhubungan dengan Power yg dikehendaki. Dengan menetapkan besar sampel $=120$, maka diperoleh Power sebesar 0,80 dalam Kategori sangat kuat. Pemilihan sampel menggunakan teknik gugus bertahap ganda. Diawali dengan memilih kelas. Tahap berikutnya adalah memilih individu yang dijadikan sampel. Sebelum dilakukan eksperimen maka dilakukan penyetaraan ketiga kelompok dengan menggunakan teknik anava satu jalur. Data yang dianalisis adalah Skor ulangan umum siswa pada semester sebelumnya. Dengan demikian maka kesetaraan antar kelompok terjaga.

Instrumen yang digunakan adalah pencatat dokumen dan tes. Pencatat dokumen diperlukan untuk memperoleh data skor ulangan umum untuk keperluan penyetaraan antar kelompok eksperimen, sedangkan tes digunakan untuk memperoleh kemampuan dalam Pemahaman Makna Pecahan (PMP), Pemahaman Konsep Pecahan senilai (PKPS), Kemampuan Operasi Penjumlahan dan Pengurangan Pecahan (KOPP) serta Kemampuan Verbal. Sebelum digunakan maka instrument tersebut diuji coba terlebih dahulu agar terpenuhi Validitas dan realibilitasnya. Teknik yang digunakan adalah uji Validitas isi oleh pakar, teknik Korelasi dan KR-20. Setelah dilakukan revisi terhadap hasil uji coba instrument maka ditetapkan bahwa instrumen tes PMP terdiri dari 22 butir, tes PKPS terdiri dari 23 butir, tes KOPP terdiri dari 24 butir dan tes Kemampuan Verbal terdiri dari 26 butir.

Teknik analisis data yang digunakan adalah analisis deskriptif dan analisis variansi dua jalur. Jika hasil uji signifikan maka dilakukan uji lanjut beda rerata. Untuk analisis deskriptif maka dilakukan dengan menkategorikan tingkat penguasaan peserta didik atas PMP, PKPS dan KOPP. Untuk itu maka digunakan rerata ideal (Mi) dan Simpangan Baku Ideal (SDi) yang diperoleh dari skor terendah ideal (Sri) dan Skor tertinggi ideal (Sti). $\mathrm{Mi}=1 / 2 \times(\mathrm{Sri}+\mathrm{Sti})$ dan $\mathrm{SDi}=1 / 6 \times(\mathrm{Sri}+\mathrm{Sti})$. Kategori yang digunakan adalah tiga kategori sebagai berikut:

Skor yang dicapai $>\mathrm{Mi}+1 . \mathrm{SDi}=$ Tinggi

Skor yang dicapai Antara Mi-1.SDi s/d Mi+1.SDi = Sedang. Jika skor yang dicapai < Mi-1.SDi = rendah Berdasarkan pengkategorian tersebut maka diperoleh kriteria pada tabel 2.

Tabel 2. Kategori Kemampuan Pecahan

\begin{tabular}{llll}
\hline Kemampuan & Rendah & Sedang & Tinggi \\
\hline PMP & $0-7$ & $8-14$ & $15-22$ \\
PKPS & $0-7$ & $8-15$ & $16-23$ \\
KOPP & $0-8$ & $9-15$ & $16-24$ \\
\hline
\end{tabular}

Tingkat kemampuan verbal dikelompokan dalam dua kategori yakni Tinggi dan rendah. Kriterianya jika skor kemampuan verbal di atas rerata maka dikategorikan tingi, dan untuk kondiosi yang lain maka dikategorikan kemampuan verbal yang rendah. Uji persyaratan analisis menggunakan Lilieffors untuk uji normalitas, dan uji Levene untuk menguji homogenitas varians. Semua analisis tersebut menggunakan bantuan program SPSS. berikut:

Hipotesis yang diuji dirumuskan sebagai

$\mathrm{H}_{01}: \alpha_{\mathrm{i}}=0$, untuk semua harga $\mathrm{i}, \mathrm{H}_{11}: \alpha_{\mathrm{i}} \neq 0$, untuk paling sedikit satu harga i. $\mathrm{H}_{02}: \beta_{\mathrm{j}}=0$, untuk semua harga $\mathrm{j}, \mathrm{H}_{12}$ : $\beta_{\mathrm{j}} \neq 0$, untuk paling sedikit satu harga $\mathrm{j}$. $\mathrm{H}_{03}: \alpha \beta_{\mathrm{ij}}=0$, untuk semua harga I dan $\mathrm{j}, \mathrm{H}_{13}: \alpha \beta_{\mathrm{ij}} \neq 0$, untuk paling sedikit satu harga I dan j. Jika analisis variansi hasilnya signifikan maka dilakukan uji lanjut beda rerata antar baris maupun antar sel.

\section{HASIL dan PEMBAHASAN}

Data hasil penelitian disajikan secara deskriptif, sebagai berikut:

Tabel 3. Statistik deskriptif skor Variabel

\begin{tabular}{lcccccc}
\hline Var. & Min & Maks & Mean & Median & Mod & SD \\
\hline Verb & 7 & 24 & 14,4 & 13,5 & 12 & 4,5 \\
PMP & 6 & 21 & 13,9 & 14 & 14 & 3,8 \\
PKPS & 7 & 19 & 12,9 & 14 & 14 & 2,6 \\
KOPP & 8 & 19 & 13,4 & 13 & 13 & 2,5 \\
\hline
\end{tabular}

Berdasarkan kategori yang telah ditentukan, selanjutnya dapat ditentukan sebaran frekuensi pada masing-masing kelompok. 
J. Pijar MIPA, Vol. 15 No.2, Maret 2020: 157-164

DOI: $10.29303 /$ jpm.v15i2.1734

Tabel 4. Frekuensi Tk Penguasaan Pecahan

\begin{tabular}{llll}
\hline Penguasaan & \multicolumn{3}{c}{ Frekuensi } \\
\cline { 2 - 4 } Pecahan & Rendah & Sedang & Tinggi \\
\hline 1.PMP & & & \\
Mdl Penglpkan & 3 & 17 & 20 \\
Mdl LD & 1 & 23 & 16 \\
Mdl Grs Bilgn & 2 & 26 & 12 \\
$\quad$ 2.PKPS & & & \\
Mdl.Penglpkan & 1 & 36 & 3 \\
Mdl.LD & 0 & 32 & 8 \\
Mdl Grs Bilgn & 0 & 30 & 10 \\
$\quad$ 3.KOPP & & & \\
Mdl.Penglpkan & 2 & 34 & 4 \\
Mdl.LD & 0 & 29 & 11 \\
Mdl.Grs Bilgn & 0 & 31 & 9 \\
& & & \\
\hline
\end{tabular}

Selanjutnya prosentase penguasaan konsep pecahan disajikan dalam Tabel berikut.

Tabel 5. Prosentase Penguasaan Pecahan

\begin{tabular}{llll}
\hline & \multicolumn{3}{c}{ Penguasan Pecahan } \\
\hline Model & PMP & PKPS & KOPP \\
\hline Penglpkan & $63 \%$ & $50 \%$ & $52 \%$ \\
Ls.Daerah & $59 \%$ & $59 \%$ & $59 \%$ \\
Grs Bilgn & $60 \%$ & $59,5 \%$ & $56,2 \%$ \\
\hline
\end{tabular}

Hasil uji Normalitas dan Homogenitas sebagai persyaratan analisis disajikan pada Tabel berikut.

Tabel 6. Hasil Uji Normalitas dan Homogenitas

\begin{tabular}{lllll}
\hline Var Terikat & \multicolumn{2}{l}{ Uji Normalitas } & \multicolumn{2}{l}{ Uji Homogenitas } \\
\hline 1.PKPS & - & - & $0,2483>0,01$ \\
Mdl.Penglpk & 0,12 & $>0,01$ & & \\
Mdl. LD & 0,08 & $>0,01$ & & \\
Mdl Grs Bil. & 0,12 & $>0,01$ & & \\
2. KOPP & - & - & $0,3654>0,01$ \\
Mdl Penglpk & 0,09 & $>0,01$ & & \\
Mdl.. LD & 0,09 & $>0,01$ & & \\
Mdl. Grs Bil & 0,13 & $>0,01$ & &
\end{tabular}

Perbedaan pengaruh dan faktor dari model A dengan taraf a1, a2, a3 dan faktor kemampuan verbal B dengan level b1 dan b2 terhadap PKPS dan KOPP dianalisis dengan anava $3 \times 2$ dengan frekuensi sel yang tidak sama. Rangkuman hasil analisis disajikan dalam tabel 7 a dan tabel $7 b$.

Dari tabel 7a dan $7 \mathrm{~b}$ nampak bahwa ketiga rumusan hipotesis statistic ditolak dengan signifikansi kurang dari $1 \%$. Hal ini menunjukan perbedaan pengaruh yang sangat berarti antar model dan antar kemampuan verbal terhadap Pemahaman Konsep Pecahan Senilai (PKPS), maupun pada Kemampuan Operasi Penjumlahan dan Pengurangan Pecahan (KOPP). Adanya interaksi antara model dengan
ISSN 1907-1744 (Cetak)

ISSN 2460-1500 (Online)

kemampuan verbal baik terhadap PKPS, maupaun terhadap KOPP menunjukka adanya ketergantungan dari penerapan model pada level kemampuan verbal.

Tabel 7a. Ringkasan Anava skor PKPS

\begin{tabular}{lccccc}
\hline $\begin{array}{l}\text { Sumb. } \\
\text { Variasi }\end{array}$ & JK & db & MK & F-hit & Sig \\
\hline $\begin{array}{l}\text { Main effect } \\
\text { Model (A) }\end{array}$ & 99,01 & 2 & 49,51 & 12,19 & $<0,01$ \\
K.Verbal (B) & 152,99 & 1 & 152,99 & 37,68 & $<0,01$ \\
Intr AxB & & 2 & & & \\
Galat & 55,484 & 114 & 27,742 & 6,833 & $<0,01$ \\
& 462,85 & & 4,06 & & \\
\hline Total & 790,59 & 119 & & & \\
\hline
\end{tabular}

Tabel 7b. Ringkasan Anava skor KOPP

\begin{tabular}{lcclll}
\hline $\begin{array}{l}\text { Sumb. } \\
\text { Variasi }\end{array}$ & JK & db & MK & F-hit & Sig \\
\hline Main effect & & & & & \\
Model (A) & 53,59 & 2 & 26,79 & 6,59 & $<0,01$ \\
K.Verbal (B) & 136,78 & 1 & 136,78 & 33,66 & $<0,01$ \\
Intr AxB & & & & & \\
Galat & 52,61 & 2 & 26,31 & 6,47 & $<0,01$ \\
& 463,32 & 114 & 4,06 & & \\
\hline Total & 723,30 & 119 & & \\
\hline
\end{tabular}

Untuk mengetahui pada level mana perbedaan itu terjadi maka dilakukan uji lanjut melalui simple effect. Hipotesis yang diuji pada pengaruh sederhana dirumuskan sebagai berikut: (1). $\mathrm{H}_{01}: \alpha_{\mathrm{i}}=0$, untuk semua harga i pada level $\mathrm{b}_{1}$, melawan $\mathrm{H}_{11}: \alpha_{\mathrm{i}} \neq 0$. (2). $\mathrm{H}_{02}: \alpha_{\mathrm{i}}=0$, untuk semua harga I pada level $b_{2}$, melawan $\mathrm{H}_{12}: \alpha_{\mathrm{i}} \neq 0$. Hasil perhitungan uji pengaruh sederhana disajikan dalam tabel 8a dan tabel 8b.

Tabel 8a. Rangkuman analisis varians dari pengaruh sederhana pada PKPS

\begin{tabular}{|c|c|c|c|c|}
\hline $\begin{array}{l}\text { Sumber } \\
\text { Variasi }\end{array}$ & JK & $\mathrm{db}$ & MK & F-hit \\
\hline A pd b & 34,69 & 2 & 17,34 & 4,27 \\
\hline$A$ pd b 2 & 120,13 & 2 & 60,07 & 14,79 \\
\hline Galat & 462,85 & 114 & 4,06 & \\
\hline
\end{tabular}

Tabel 8b. Rangkuman analisis varians dari pengaruh sederhana pada KOPP

\begin{tabular}{llcll}
\hline $\begin{array}{l}\text { Sumber } \\
\text { Variasi }\end{array}$ & \multicolumn{1}{c}{ JK } & Db & MK & F-hit \\
\hline A pd b & 5,82 & 2 & 2,91 & 0,712 \\
A pd b & 100,65 & 2 & 50,12 & 12,33 \\
Galat & 463,32 & 114 & 4,06 & \\
\hline
\end{tabular}

Jika dibandingkan dengan F-tabel pd taraf nyata $1 \%, \mathrm{db}_{1}=2$ dan $\mathrm{db}_{2}=114$ maka diperoleh nilai F-tabel $=4,79$. Ini berarti pengaruh sederhana dari faktor A (Model) pada level $b_{1}$ (kemampuan verbal 
tinggi) baik pada PKPS maupun pada KOPP menunjukkan hasil yang tak signifikan. Karena F-hit $<$ F-tabel $\left(4,27\right.$ dan 0,712 < 4,79). Sehingga $\mathrm{H}_{01}$ ditolak. Ini berarti bahwa belum cukup bukti untuk mengatakan bahwa model penyajian pecahan mempunyai pengaruh yang berbeda terhadap Pemahaman Konsep Pecahan Senilai (PKPS), maupun pada Kemampuan Operasi Penjumlahan dan Pengurangan Pecahan (KOPP), jika diterapkan pada kelompok siswa yang berkemampuaan verbal tinggi (level $b_{1}$ ).

Pengaruh sederhana dari faktor A pada level $\mathrm{b}_{2}$ sangat signifikan, karena harga F-hit > Ftabel pada taraf nyata $1 \%$. Keputusannya bahwa $\mathrm{Ho}_{2}$ ditolak, ini berarti bahwa model penyajian pecahan memberikan pengaruh yang berbeda secara signifikan terhadap PKPS, maupun KOPP pada kelompok siswa yang berkemampuan verbal rendah. Akibat adanya pengaruh yang berbeda terhadap ketiga kelompok penyajian pecahan, maka perlu dilakukan uji untuk mengetahui pada sub kelompok mana perbedaan itu terjadi. Hal ini dilakukan dengan mengadakan pelacakan beda rerata antarsel pada tingkat kemampuan verbal rendah. Pelacakan dilakukan dengan menggunakan statistik uji :

$\mathrm{t}=\frac{\left(\mathrm{X}_{\left.\mathrm{ij}-\mathrm{X}_{\mathrm{kj}}\right)}\right.}{\sqrt{\operatorname{MSw}\left(\frac{1}{\mathrm{n}_{\mathrm{ij}}}+\frac{1}{\mathrm{n}_{\mathrm{kj}}}\right)}}$ yang berdistribusi student dengan

$\mathrm{db}=\mathrm{N}-\mathrm{pq}=120-(3) .(2)=114$ (Winer, 1971). Besar rerata skor PKPS dan KOPP pada masing-masing sel pada tabel 9a.

Tabel 9a. Rerata skor PKPS pada tiap sel

\begin{tabular}{lll}
\hline \multirow{2}{*}{ Fakt. B } & \multicolumn{2}{c}{ Kemampuan Verbal } \\
\cline { 2 - 3 } Fakt. A & \multicolumn{1}{c}{ Tinggi(b1) } & Rendah(b2 \\
\hline Modl Penglpkan (a1) & $\mathrm{M}=13,53$ & $\mathrm{M}=9,91$ \\
& $\mathrm{n}=17$ & $\mathrm{n}=23$ \\
Modl. Luas Daerah (a2) & $\mathrm{M}=13,67$ & $\mathrm{M}=13,27$ \\
& $\mathrm{n}=18$ & $\mathrm{n}=22$ \\
Modl. Grs Bilangan(a3) & $\mathrm{M}=15,22$ & $\mathrm{M}=12,41$ \\
& $\mathrm{n}=18$ & $\mathrm{~N}=22$ \\
\hline
\end{tabular}

Tabel 9b. Rerata skor KOPP pada tiap sel

\begin{tabular}{lll}
\hline \multirow{2}{*}{ Fakt. B } & \multicolumn{2}{c}{ Kemampuan Verbal } \\
\cline { 2 - 3 } Fakt. A & \multicolumn{1}{c}{ Tinggi(b1) } & Rendah(b2 \\
\hline Modl Penglpkan (a1) & $\mathrm{M}=14,29$ & $\mathrm{M}=10,91$ \\
& $\mathrm{n}=17$ & $\mathrm{n}=23$ \\
Modl. Luas Daerah (a2) & $\mathrm{M}=14,39$ & $\mathrm{M}=14,09$ \\
& $\mathrm{n}=18$ & $\mathrm{n}=22$ \\
Modl. Grs Bilangan(a3) & $\mathrm{M}=15$ & $\mathrm{M}=12,23$ \\
& $\mathrm{n}=18$ & $\mathrm{~N}=22$ \\
\hline
\end{tabular}

Hasil uji beda rerata antar sel dinyatakan dalam tabel $10 \mathrm{a}$.
Tabel 10a: Komparasi rerata antar sel skor PKPS

\begin{tabular}{lccc}
\hline $\begin{array}{l}\text { Komparasi } \\
\text { Rerata }\end{array}$ & t-hitung & t-tabel & $\begin{array}{c}\text { Kesim } \\
\text { pulan }\end{array}$ \\
\hline Sel 12 vs Sel 22 & 5,59 & 2,36 & Sign. \\
Sel 12 vs Sel 32 & 4,13 & 2,36 & Sign. \\
Sel 22 vs Sel 32 & 1,42 & 2,62 & Non.Sign. \\
\hline
\end{tabular}

Oleh karena rerata $\operatorname{sel}_{22}(=13,27)>$ rerata $\operatorname{sel}_{12}(=9,91)$, dan rerata $\operatorname{sel}_{32}(=12,41)>$ rerata $\mathrm{sel}_{12}$ maka dapat disimpulkan bahwa penyajian konsep pecahan dengan model Luas Daerah lebih baik dari model Pengelompokan. Begitu pula model Garis Bilangan lebih baik dari pada model pengelompokkan. Namun hal ini hanyalah berlaku pada kelompok peserta didik yang berkemampuan verbal rendah. Antara model luas daerah dan model garis bilangan penerapannya pada kelompok siswa yang berkemampuan verbal rendah mempunyai pengaruh yang sama.

Berikutnya terhadap KOPP diperoleh hasil seperti dalam tabel $10 \mathrm{~b}$.

Tabel 10b. Komparasi rerata antar sel skor KOPP

\begin{tabular}{lccc}
\hline $\begin{array}{l}\text { Komparasi } \\
\text { Rerata }\end{array}$ & $\begin{array}{c}\mathrm{t}- \\
\text { hitung }\end{array}$ & $\begin{array}{c}\mathrm{t}- \\
\text { tabel }\end{array}$ & $\begin{array}{c}\text { Kesim } \\
\text { pulan }\end{array}$ \\
\hline Sel 12 vs Sel 22 & 5,29 & 2,36 & Sign. \\
Sel 12 vs Sel 32 & 2,20 & 2,36 & Non Sign. \\
Sel 22 vs Sel 32 & 3,08 & 2,62 & Sign. \\
\hline
\end{tabular}

Oleh karena rerata $\operatorname{sel}_{22}(=14,09)>$ rerata $\operatorname{sel}_{12}(=10,91)$, dan rerata $\operatorname{sel}_{22}>{\text { rerata } \operatorname{sel}_{32}(12,23)}$ maka dapat disimpulkan bahwa penyajian konsep pecahan dengan model Luas Daerah lebih baik dari model Pengelompokan maupun model garis bilangan pada tingkat siswa berkemampuan verbal rendah. Antara model pengelompokkan dan model garis bilangan mempunyai pengaruh yang sama.

Adanya pengaruh interaksi antara faktor model penyajian dengan kemampuan verbal dalam skor kemampuan PKPS dapat disajikan ke dalam grafik pada gambar 1 .

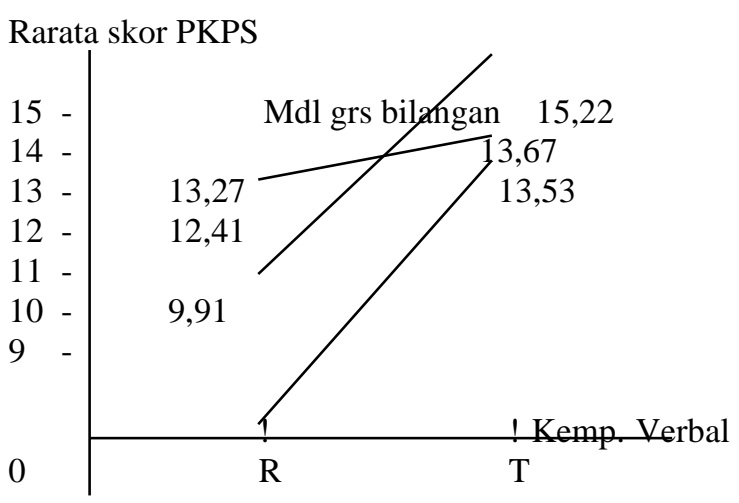

Gambar 1. Interaksi ketiga model terhadap PKPS 
Grafik interaksi pada skor KOPP dapat dinyatakan pada gambar 2 :

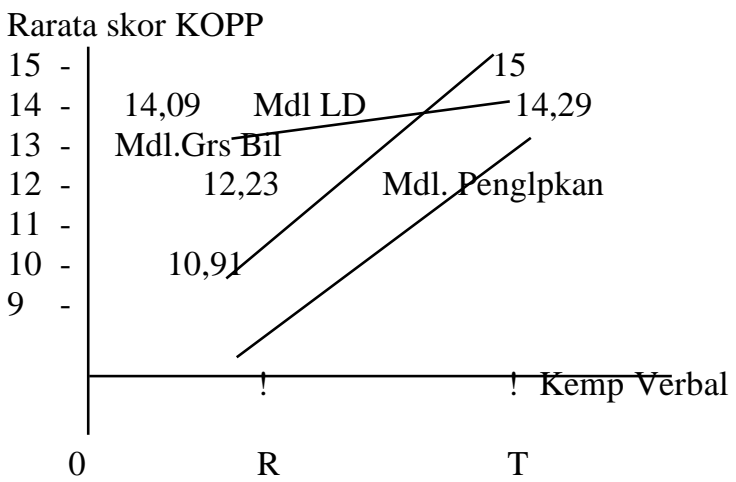

Gambar 2. Interaksi ketiga model terhadap KOPP

Dari ke dua grafik intraksi tersebut di atas, tampak bahwa garis yang menggambarkan pembelajaran dengan model luas daerah mengalami tanjakan yang relative kecil dan tak berarti. Hal ini menunjukkan bahwa pengaruh dari pembelajaran dengan model luas daerah relative sama pada kemampuan verbal rendah maupun tinggi, baik pada skor PKPS maupun KOPP. Berbeda halnya dengan garis yang menggambarkan penyajian konsep pecahan dengan pengelompokkan maupun garis bilangan. Kedua garis ini mengalami tanjakan yang cukup tinggi. Hal ini berrati bahwa pengaruh dari kedua model penyajian konsep pecahan tersebut tergantung dari tingkat kemampuan verbal peserta didik. Makin tinggi tingkat kemampuan verbal siswa maka makin tinggi rerata skor yang dicapainya.

Adanya perpotongan garis dari pembelajaran pecahan dengan penyajian model luas daerah dengan model garis bilangan, menunjukkan bahwa pada tingkat kemampuan verbal tertentu kedua model pembelajaran tersebut mencapai hasil yang sama. Secara matematis hal ini dapat ditentukan dengan mencari titik potong dari ke dua garis tersebut.

\section{KESIMPULAN}

Berdasarkan hasil penelitian maka dapat disimpulkan bahwa: (1) Rerata skor hasil tes penguasaaan konsep pecahan yang meliputi PMP, PKPS, dan KOPP pada masing masing kelompok model penyajian berada pada kategori sedang. Prosentase tingkat penguasaan materi tentang konsep pecahan (PMP, PKPS, KOPP) pada kelompok penyajian konsep pecahan dengan Model Pengelompokan, berturut-turut adalah 63\%, 50\% dan 52\%. Pada kelompok Model Luas Daerah berturut-turut tingkat penguasannya adalah $65,8 \%$, $59 \%$ dan 59\%. Pada kelompok Model Garis Bilangan berturut-turut adalah $60 \%, 59,5 \%$ dan $56,2 \%$. (2) Dalam menanamkan pemahaman siswa atas konsep pecahan senilai, penyajian konsep pecahan dengan model Luas Daerah dan model
Garis Bilangan sama efektivitasnya, namun keduanya lebih efektif dari penyajian konsep pecahan dengan model Pengelompokan. (3) Pengaruh model penyajian konsep pecahan terhadap PKPS maupun KOPP sangat tergantung dari tingkat kemampuan verbal siswa. (4) Terhadap KOPP maka penyajian dengan model Luas Daerah merupakan yang paling efektif dibandingkan dengan yang lainnya.

\section{DAFTAR PUSTAKA}

[1] Soedjadi. (1999). Kiat Pendidikan Matematika di Indonesia. Jakarta: Ditjen Dikti Depdiknas

[2] Jacks, S.M. \& Peck, D.M. (1981). Conceptual issues in the Theaching and Learning of Fraction. Journal for Research in Mathematics Education. 12(5).339-348.

[3] Gatot Muhsetyo, dkk. (2014). Pembelajaran Matematika SD. Jakarta: UT

[4] Akbar Sutawijaya, dkk. (1993). Pendidikan Matematika 3. Jakarta: Depdikbud, Dirjendikti, P2TK

[5] Woodworth, R.S., Marquis, D.G.(1955). Psychology. London: Methuen

[6] Winkel, W.S. (1991). Psikologi Pengajaran. Jakarta: PT Gramedia.

[7] Ruseffendi, E.T.(1980). Pengajaran Matematika Modern untuk Oarng Tua Murid Guru dan SPG. Bandung: Tarsito.

[8] Dienis, Z.P. (1971). Building up Mathematics, ( ${ }^{\text {th }}$ ed.). London: Hutchinson Educatioal.

[9] Bell, A.W., J. Castello, \& D.E. Kucheman (1983). A review of research in Mathematical Educational Part A. London: NFER-Nelson.

[10] Darhim, dkk. (1991). Pendidikan Matematika. Modul 1-7. Jakarta: Depdikbud Dirjendikti, P2TK

[11] Anisa, A. (2018). Matematika Dan Anak. Jurnal Matematika, Statistika dan Komputasi, 2(2), 70-74.

[12] Gagne, R.M. (1970). The Condition of Learning, ( $2^{\text {nd }}$ ed). New York: Holt Reinhart \& Winston

[13] Sheppard, J.L. (1975). Verbal Analysis and Concreet Operation. The Australian Journal of Education. 19. 26-37

[14] Kennedy, L.M. (1970). Guiding Children to Mathematical discovery. Belmont, CA: Wodsworth.

[15] Cohen, L. (1977). Statisticaj Power Analysis for the Behavioral Scienes (rev. ed). New York: Akademic Press. 